The Geological Society of America

Special Paper 552

\title{
Is geoheritage a "cutting-edge" science? Promotion of an extension to the definition of geoheritage with emphasis as a significant discipline in geosciences with cultural and societal relevance
}

\author{
Anne Ewing Rassios* \\ Hellenic Survey of Geology and Mineral Exploration, Region of West Macedonia, Lefkovrisi, Kozani 50100, Greece \\ Giovanni Grieco \\ Dipartimento di Scienze della Terra “A. Desio," Università degli Studi di Milano, Via Botticelli, 23 Milano, Italy
}

\begin{abstract}
Geoheritage documentation is critical for the academic community, and thus incurs an expense to the general public, who may or may not feel the need to fund such an "academic" database. Fortunately, this documentation helps foster appreciation of geosites within a geotouristic framework and can inspire a nationalistic sense of pride, thus bringing about an economic incentive to countries actively involved in geoheritage research and documentation. Yet there remains a prejudice within academia that geoheritage is a descriptive field, is arbitrarily qualitative, and lacks the capacity to create new and important scientific discoveries. We present herein a description and discussion of the results of applying "cutting-edge" science in a geoheritage framework with ample examples from Greece and two case studies of its application. The first of these is The Aliakmon Legacy Project of Northern Greece that necessitated modern documentation to preserve its heritage base when plate tectonic global geoheritage localities were flooded. The second summarizes the geologic history of the Meteora World Heritage Site with an emphasis on how its long complex geologic history ultimately resulted in the Byzantine Monastic community. We propose this paper as a discussion model for the integration of primary geologic research with cultural heritage localities and emphasize that these promise to elevate geoheritage studies to a scale critical for documentation of human civilization itself. It is our opinion that geoheritage is capable of becoming a dynamic field of study in which documentation and preservation expands to integrate renewed multidisciplinary research that in turn comprises the scientific foundation of a "new" cuttingedge geologic field of study.
\end{abstract}

\footnotetext{
*rassanie@gmail.com
}

Rassios, A.E., and Grieco, G., 2021, Is geoheritage a "cutting-edge" science? Promotion of an extension to the definition of geoheritage with emphasis as a significant discipline in geosciences with cultural and societal relevance, in Wakabayashi, J., and Dilek, Y., eds., Plate Tectonics, Ophiolites, and Societal Significance of Geology: A Celebration of the Career of Eldridge Moores: Geological Society of America Special Paper 552, p. 37-53, https://doi.org/10.1130/2021.2552(03). (c) 2021 The Geological Society of America. All rights reserved. For permission to copy, contact editing @ geosociety.org. 


\section{INTRODUCTION AND PARADIGM}

For all who ever received an email from Eldridge Moores, you will recognize this as his most cherished quotation: "Civilization exists by geologic consent, subject to change without notice" (Will Durant). It is the integration of this philosophy within the realm of geoheritage that inspires the following discussion.

\section{A Country is Born of Its Geology}

The history of a country is intrinsically linked to its geologic legacy. Mineral wealth and fluctuations in mineral economics in the past and present remain critical to national developmental policies. Seismic or volcanic activity could be critical to the environment of an agricultural base, the evolution of a population or a society, the preservation of buildings and cultural sites, and even to the evolution of new species. The geologic environment is as important to the evolution of the human race as it is to the present economic evolution of countries.

There is great academic interest in preserving recognized geologic phenomena that are, and will remain, archetypical localities in the advancement of geologic science. The assessment of such "geosites" has an economic and sociological benefit: the potential for documentation and promotion of geosites includes localities of cultural and historical prominence, and sites of such supreme beauty that they can be incorporated into advantageous geotouristic and/or touristic development. Those countries that locate and document these sites have an inherent economic advantage over countries that, though they contain preeminent sites, fail to recognize and market these sites as touristic features.

The valuation of a geosite can be difficult to insert into a data repository that necessitates quantitative appraisal of qualitative factors (Leleniczi, 2009; Fassoulas et al., 2012), and yet qualitative evaluations of geosites are essential for their assessment within infrastructural planning, preservation, and resource development. These numeric analyses require quantitative judgments. For example, how does a geologist rate the importance of a sedimentary versus an igneous environment? How can a comparison be made between a "local" site to global-scale phenomena when no researcher can investigate all such sites worldwide? How does one produce an evaluation when the research on a site may be insufficient for understanding its ultimate value in geological theory?

How does one effectively quantify a geomorphologic feature when, frankly, the beauty and awe of a site is indeed in the "eyes of the beholder"?

At present, the documentation of geosites is equivalent to the cataloguing of specimens in a museum, albeit a museum on the scale of the entire planet. The understanding of geosites, geologic specimens, and geo-localities is integral not just to geologists, but to understanding environmental conditions critical to turning points of earth history, human history, and species/biotope evolution. We propose herein an expansion in the study of geoheritage that will necessitate a more challenging multidisciplinary research base and promote a better understanding of the union of geology with human civilization.

Every rock and every rock outcrop are unique; the importance of every rock and outcrop is unique as well. There can be no consensus as to what is, and what is not, a "geosite" without assessment within the framework of its importance to the regional geologist and indigenous cultural population.

The standing definition of a geoheritage site (Semeniuk, 1997; Brocx and Semeniuk, 2007) is as follows (quotation from Semeniuk, 1997): "Globally, nationally, state-wide, to local features of geology, such as its igneous, metamorphic, sedimentary, stratigraphic, structural, geochemical, mineralogic, palaeontologic, geomorphic, pedologic, and hydrologic attributes, at all scales, that are intrinsically important sites, or culturally important sites, that offer information or insights into the formation or evolution of the Earth, or into the history of science, or that can be used for research, teaching, or reference." We agree with this definition but wish to take it a step forward.

The framework paradigm for creating a new, more active approach to geoheritage research is found in the quotation above by historian and philosopher Will Durant (1946): it is, as we propose within our expanded definition (below), essential to investigate "what is" that geological consensus that constrains the development and existence of human civilization. How is geologic history interwoven with the rocky foundations needed to support, or fail to support, a civilization? We believe that ascertaining this answer is within the study of geoheritage, in particular as applied to specific cultural settings. The work of Heiken et al. (2007) on the importance of geology as an essential factor in the development of today's Rome opens a bold footpath to such studies worldwide. To qualify these studies requires an evolution in the methodology of geoheritage research.

The goal of this discussion is to reintroduce the concept of geoheritage as an essential cutting-edge division within the study of geology: we will review/describe the physical components of "geoheritage" that overlap critical points of scientific and social importance, and remind how studies of such sites inspired by geoheritage can result in ground-breaking scientific interpretations. We propose the following expansion to the standing definition of geoheritage that incorporates its significance into a Will Durant world view: Geoheritage is the union of the study of geology as a science with the recognition and importance of geology to human society.

\section{COMPONENTS OF GEOHERITAGE}

Geoheritage appreciation includes a complex, interrelated collection of diverse types of geo-localities. For each type that we describe in this section, we point out an example of resulting cutting-edge science that has invigorated research and promoted the popular interest of the non-geological world:

A geosite (also referred to as a geotope) could be an "invisible" line separating a dark gray rock from a light gray rock that is of interest only to a specialist researcher; however, the documentation 
of this contact is critical for generations of geoscientists that follow in the pioneering paths of historic researchers. The primary example of the importance of such a simple phenomenon as that of a geologic contact or fossil locality could be analogous to the now worldwide studies and implications of the Cretaceous/Paleogene boundary (e.g., Alvarez et al., 1980; Schulte et al., 2010). In our example from the Vourinos Ophiolite of Central Greece (Fig. 1A), we show part of a dark rock/light rock contact (Fig. 1B) that, to explain, necessitated incorporation of ophiolitic suites as emplaced oceanic lithosphere in the initial elucidation of plate tectonic theory (Moores, 1969; Zimmerman, 1968).

Geomythology and the recording of traditional interpretations of geologic phenomena plays an intrinsic role for the geologic researcher (Fig. 2) and can be critical to the preservation of cultural heritage: the search for the geologic source of myths and legends has proven to promote cutting-edge studies of (among other
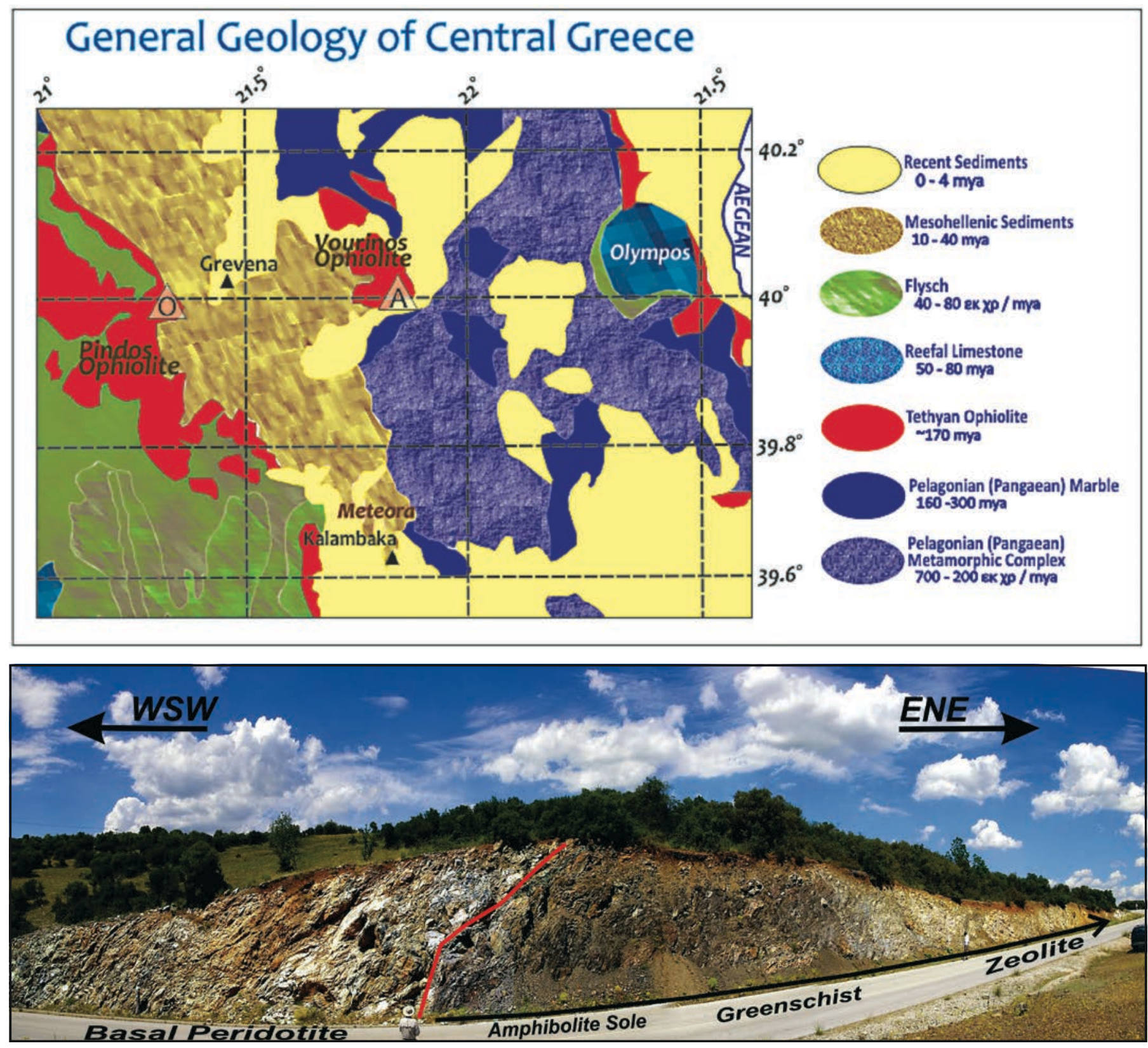

Figure 1. (A) General geologic formations within central-northern Greece, areas and sites referred to in present work. Small triangles refer to "A" Site of Aliakmon Legacy Project (Figs. 1B, 7, 8, 9, and 10), "O" Site of Orliakas "Face of Zeus" Geomorph (Fig. 3), and Portitsa Geowonder (Fig. 4). (B) A "line" separating a dark rock from a light rock (center of photo). In this case, this line is the emplacement amphibolite sole of the Vourinos Ophiolite (center of photo) and comprises one of the initial critical sites for the documentation of plate tectonic theory. View is toward the north (west to left of photo, east to right of photo). 


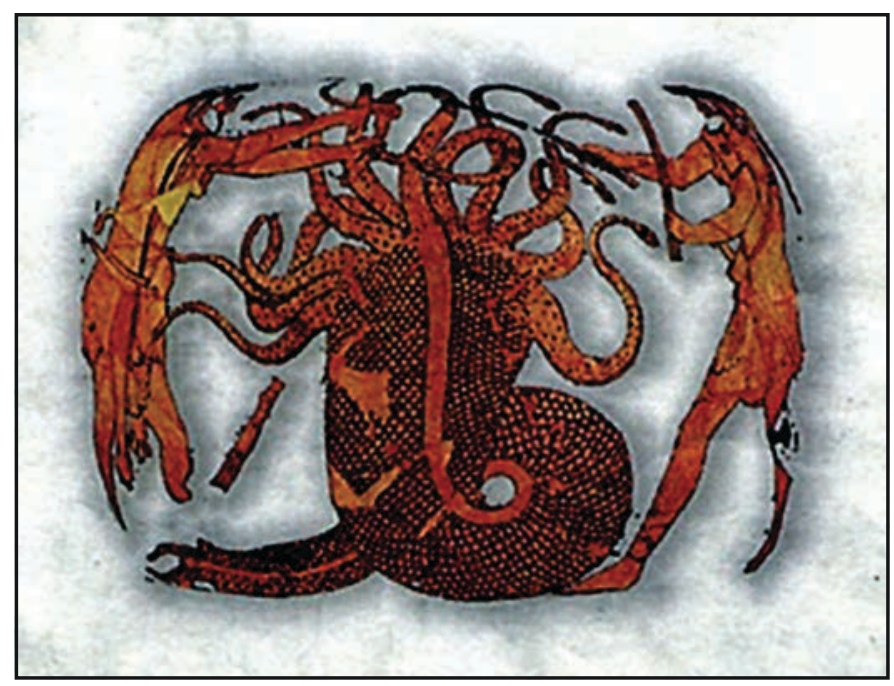

Figure 2. From the work of Ilias Mariolakos (1998): Herakles in battle against the Lernea, Hydra at Lernea, Greece. The modern hydrologist faces the same battle at Lernea today - the monster's heads emanating as karstic springs. With each spring head cut off, several new springs arise to takes its place. This has led to the tongue-in-cheek suggestion by pioneer geomythologist researcher Ilias Mariolakos that Hercules was a plumber!

localities) the Black Sea as a model for Noah's Flood (Aksu et al., 2002; Ryan et al., 2003; Dimitrov and Dimitrov, 2004; Ryan, 2007).

A geomorph could be a rock formation shaped like an animal or in some odd shape that is appreciated by the local population (Fig. 3); in this case, the role of the geoheritage worker is to translate scientific observation to the popular interpretation of such "geomorphs." An example where geologic impact is deemed essential to understanding archaeological sites would include the Sphinx, now speculated to be built upon a geologic formation that inspired its construction (Raynaud et al., 2008), as well as the presence of the geomorphs of bulls' horns that possibly influenced the location of the Knossos site of Crete (Schama, 1995).

Geowonders (as defined by A. Rassios) are localities that inspire a state of awe in those who observe them (Fig. 4):

Figure 4. A geowonder site weaves immense beauty with cultural and geological history. This photo shows an example where a mythological river spirit, too impatient to await erosional processes, split a gorge (Portitsa Gorge, Pindos Mountains, Greece: 3959.761'N; $21^{\circ} 17.131^{\prime} \mathrm{E} ; 676 \mathrm{~m}$ elevation). This fault-bounded catastrophic canyon is within the region where Alexander the Great hunted boar, deer, and bear, according to legend. The stones are rich in Cretaceous fossil rudists. The stone bridge (constructed in 1743; funded by a Byzantine Monastery within Spelio Village) creates a cultural icon for the SpelioGrevena area. The position of this and nearby bridges illustrates trade routes of the era; studies of the stones used in the bridge construction (some derived from a locality $\sim 30 \mathrm{~km}$ to the north) illustrate building techniques and economic-trade development of the period.

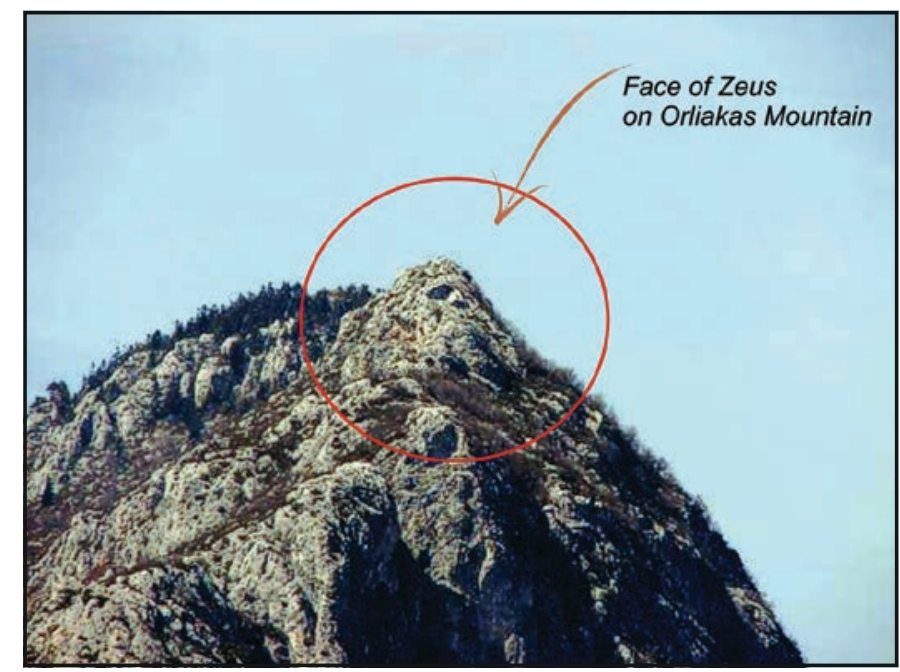

Figure 3. The Face of Zeus: Mount Orliakas, Pindos Greece $\left(40^{\circ} 0.681^{\prime} \mathrm{N} ; 21^{\circ} 16.763^{\prime} \mathrm{E} ; 1170 \mathrm{~m}\right.$ elevation). This rocky peak (a geomorph or "mimetolith") resembles the head and beard of the ancient god Zeus. Zeus is situated on this face of Orliakas Mountain in such a way that he is looking directly toward Mount Olympos. The site is adjacent to several Neolithic and Hellenistic settlements. Did the vision of the god influence the early habitation of the area?

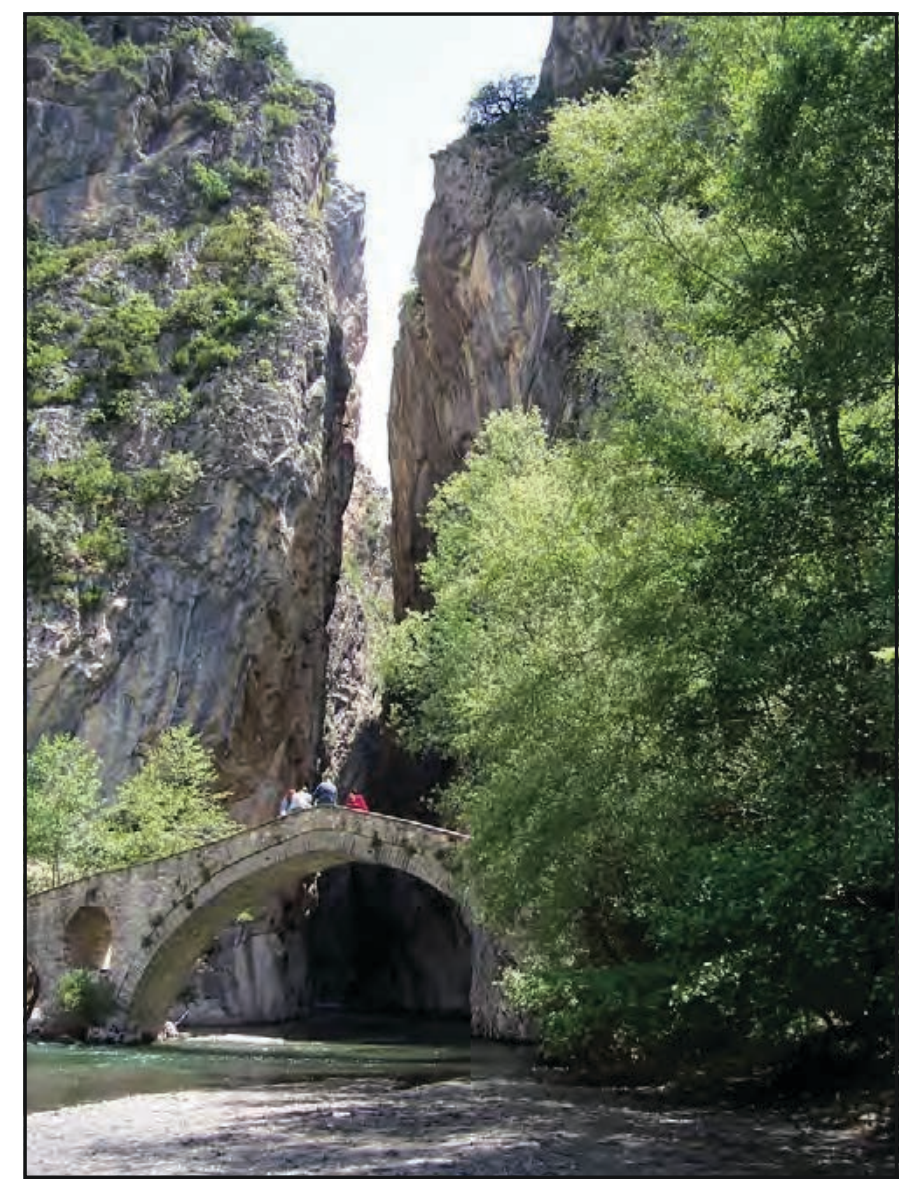


mountain peaks, views of landscapes, rock formations displaying beautiful colors or designs, deep valleys. These are features that create a touristic infrastructure and form the basis of national parks around the globe. Their description as geologic phenomena add a dimension of beauty and understanding that increases both comprehension and inspiration of the site. The documentation of the visible history exposed through the viewing of a geowonder can necessitate a study of geodiversity that includes billions of years of geologic history in fields as varied as plate tectonics, glaciation, paleontology, and geo-archaeology. Would the Grand Canyon have been studied in such amazing detail were it not, among other things, a geowonder?

Geoethnology is the study of geographic and geologic phenomena that impact the sociologic evolution of a people and their culture (see for example, Barker and Barker, 1988) (Fig. 5). A common example given is the development of the "city state" in ancient Greek history based on the geographically rugged host terrain naturally separating human settlements into independent regions, each with a distinct sub-environment and diverse natural resources. Understanding the ancient cultures of, for example, Thessaly versus Attica requires a geologic-geographic knowledge base. The rocky geologic setting of the Peloponnese is, to a great extent, one of the formative characteristics to the ancient Spartan culture.

Geohistoric sites are the sites that, because of their geologic and geographic character, have controlled human history. The geologic and geographic landscape can control the tactics of battles and progress of wars, the migration and trade routes of civilizations, or the confluence of ethnic boundaries and cultures (Fig. 6). Would there have been a Greek democracy had the geologic processes that created a hill now called "The Acropolis" not taken place? Would there have been the same outcome to the war of Caesar against Pompey at Farsala (Central Greece) if the geographic setting of the battlefield were different, changing the outcome of the defining battle that initiated the foundation of the Roman Empire? To answer these questions, speculation must be replaced by research — hard scientific research - that includes the geologic and geographic evolution of these sites as well as cultural and battlefield strategy.

Geoparks (Zouros, 2004) are a relatively recent addition to the confluence of geologic setting and societal relevance. As described by Moores (2018), the initial organizational discussions of geoparks began in the late 1990s with the goal of recognizing regions important to geological paradigms and conservation of geologic field localities. Geoparks include the geomorphic sites of beauty that attract mass tourism. Thus, they have become economically important to the regional communities hosting a geopark. UNESCO now sponsors an international network of geoparks, each considered "a unified area that advances the protection and use of geological heritage in a sustainable way, and promotes the economic well-being of the people who live there" (McKeever and Zouros, 2005). Though not part of the UNESCO movement, the National Parks of the USA that are established in part because of their beauty and the rarity of their natural geo- logic environments are de facto geoparks. To quote the UNESCO Global Geoparks site: "Dream. Explore. Discover!"

\section{EXAMPLES OF GEOHERITAGE "CUTTING-EDGE" INVESTIGATIONS}

The prevailing questions for studies of all geoheritage localities are these:

(i) What are the critical geologic processes or events that resulted in formation of the site under study?

(ii) Would world history have been affected if geologic terrains were different in character?

(iii) How, indeed, does geology affect critical developments in human civilization?

\section{GEOHERITAGE WITHIN OUR EVOLVING GEOLOGIC PARADIGM}

The past century has witnessed revisions of the consensus geologic framework multiple times: in chief, the advancement from a geosynclinal framework paradigm to plate tectonics, to the elucidation of terrane theory and practicalities of exhumation models. Geoheritage sites defined in context of past frameworks require scientific updating to keep up with the evolution of geologic thought. This updating itself contributes to newly developing frameworks, a process universal to all "scientific revolutions" (Kuhn, 1962). We include below two of our research examples in which geoheritage documentation resulted, somewhat unexpectedly, in cutting-edge advances to geologic interpretation.

\section{GEOHERITAGE PRESERVATION WHEN GEOLOGY CAN'T BE PRESERVED}

In the early years of formulation of plate tectonic theory, the Vourinos Ophiolite Complex of Greece played a significant role in documentation of requisite observations leading to the new paradigm (Zimmerman, 1968, 1969, 1972; Moores, 1969, 2003). The exposures within the valley of the Aliakmon River near the Zavordas Monastery (Figs. 7 and 8A) were among the most critical: the same sites had been recognized by Brunn (1956; personal documentation, https://www.geoparkgrevenakozani.com/2021/01/our-geoheritage.html; accessed June 2021) as perhaps the most important global example of an ophiolitic base within the context of geosynclinal theory.

The geoheritage area along the Aliakmon River includes a great extent of the outcrop of the emplacement sole of the Vourinos Ophiolite and a structural complexity that could only be explained by the collision of tectonic plates (Fig. 8B). Though frequently visited by international researchers over the decades as a field trip destination, renewed research on the river site was not conducted; science advanced, but the observations on the river section remained in the framework of late 1960s geology. At that time, geology lacked understanding of kinematic indicators, of ductile deformation mechanisms, and of key mineralogic 


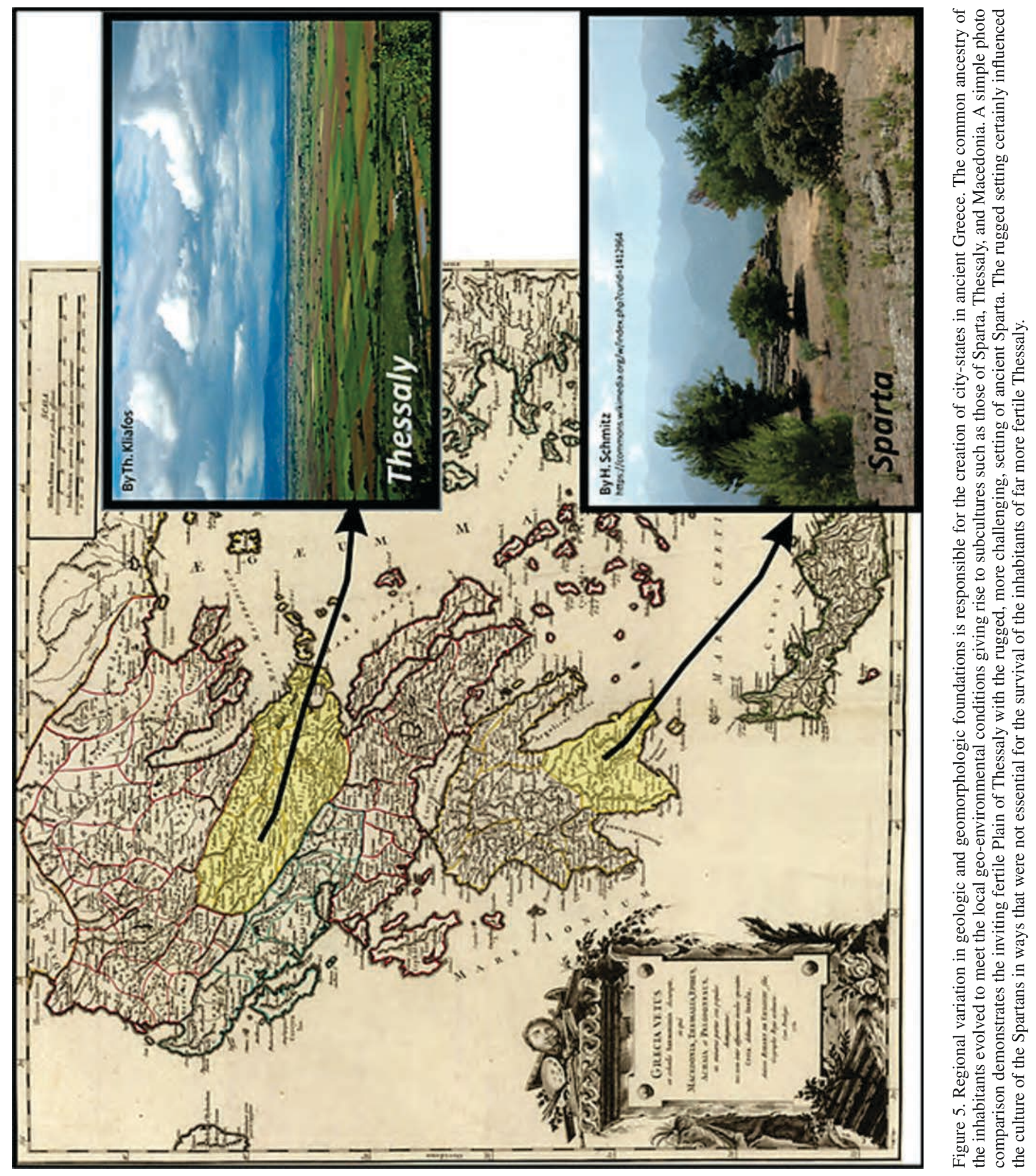



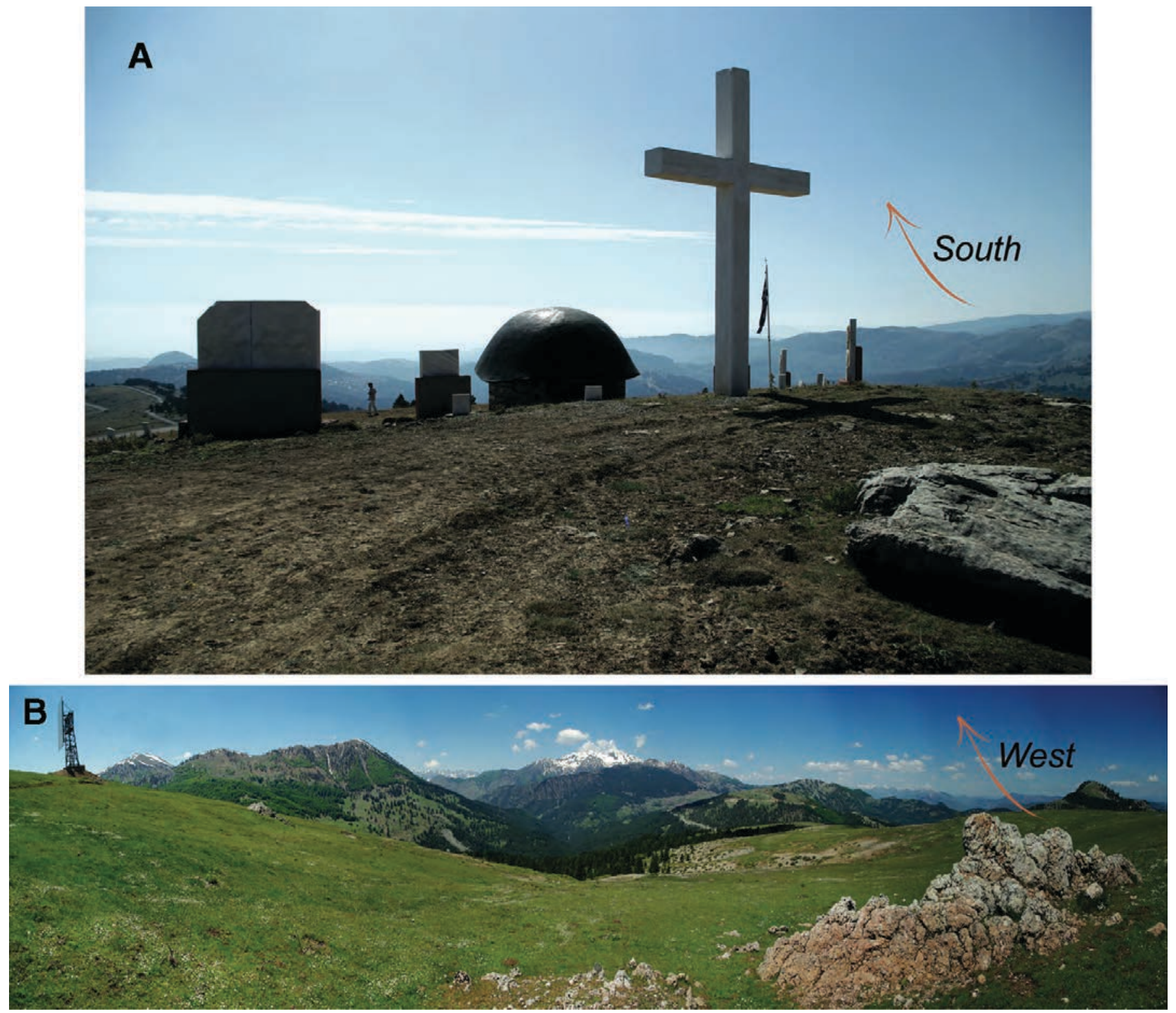

Figure 6. (A) The memorial to the battle grounds $\left(40^{\circ} 5.666^{\prime} \mathrm{N} ; 21^{\circ} 5.460^{\prime} \mathrm{E} ; 1692 \mathrm{~m}\right.$ elevation), marking the entrance of Greece into World War II at Annitsa, Pindos Mountains. The initial fighting following Greece's famous "Oxi!" (No!) to the advancement of Axis forces was in an inhospitable, geographically anomalous region. (B) The knowledge base of the Greek fighters of this terrain was a critical component to their early victories $\left(40^{\circ} 5.606^{\prime} \mathrm{N} ; 21^{\circ} 5.141^{\prime} \mathrm{E} ; 1704 \mathrm{~m}\right.$ elevation). A $360^{\circ}$ panorama from the site (about a third shown within photo) allowed full visual access of troop movements in an area of over $2000 \mathrm{~km}^{2}$; the small outcrop of reefal conglomerate within the flysch is one of many scattered in the locality that serve as natural barricades/bunkers for resistance fighters.

temperature/pressure conditions such as for garnet amphibolite ophiolitic soles.

Long-term plans for the creation of a hydroelectric dam on the Aliakmon River that would flood this geoheritage area began implementation in the first decade of the new millennium. This would mean that sites integral to the original formulation of plate tectonic theory would be lost. A program was put forward to the Public Power Company of Greece and funding given to aid a final description of the geology of the river section (Rassios et al., 2016).
There was a lot of catching up to do: when initial studies of the Aliakmon Valley were done in the late 1960s, there was essentially no knowledge base on kinematic indicators, geochemical associations, or anything to do with rifting and consuming plate processes.

We also faced the important question: who were to be the recipients of this geoheritage? Who should be among those responsible for learning about these sites and who could then pass down the information? 


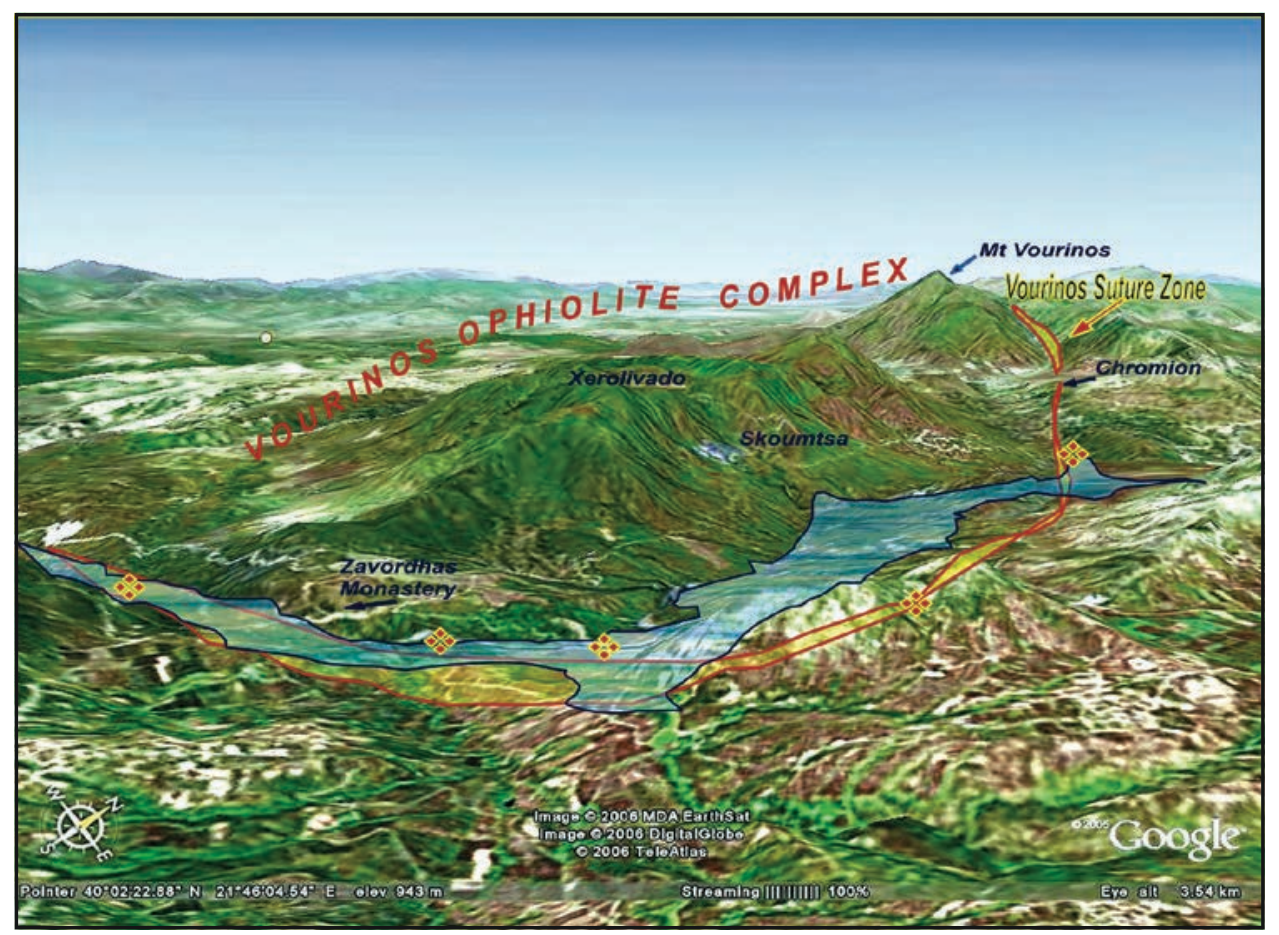

Figure 7. Vourinos Ophiolite, Greece. Geoheritage sites (yellow-red crosses) mark some of the "birthplace" localities of plate tectonic theory that were flooded with the new hydroelectric dam. This Google Earth image ca. 2004 demonstrates the pre-reservoir terrane that was flooded in 2012.

The solution turned into a four-year program involving $~ 66$ international researchers, the majority being students using the program to fulfill their mapping and diplomatic thesis requirements. Who better than students to learn the importance of a geoheritage site and then pass this information to those who would become their students and collaborators in decades to come? Participants included students from Cambridge University, the University of Edinburgh, the University of Milan, the University of Cologne, Miami University, the State University of New York, the universities of Greece, and the Institute of Geology and Mineral Exploration of Greece. Approximately 40 student theses were produced, six M.Sc. dissertations, and a number of academic papers (e.g., Ghikas et al., 2010, still more papers being added). Student teams were accompanied by their professorial advisors, including notably: Prof. Yildirim Dilek (Miami University), Prof. Emeritus. Alan Smith (Cambridge University), G. Grieco (University of Milan), Prof. A. Robertson (University of Edinburgh), Dr. D. Kostopoulos (University of Athens), and T. Reinsch (then University of Cologne).

Is field mapping cutting-edge research (Fig. 9)? Primary observation and documentation of geological sites is inherently cutting edge. Brunn's map of the area (Brunn, 1956) remains a paradigm of primary pioneering mapping: his base map consisted of a 1:100,000-scale topographic map dating from the 1880s. The mapping by Moores and Zimmerman (Moores 1968; Zimmerman 1968) lacked detailed topographic maps. Our study provided up-to-date, 1:5000 scale topographic maps and aerial photographs for the researchers. Mapping of the area employed GIS technology for the first time, with photography documentation via GPS locations. Geochemical and metamorphic tech- niques and interpretation were applied to the original study sites that were not even envisioned as study techniques in the 1960s. Yes, field mapping is cutting-edge research; re-mapping parallel to the evolution of geological consensus and methodology reveals a depth of new information from "old" sites.

Petrologic sample collections were also linked to GPS localities, and included representative and "oddities" of the geologic diversity of the river canyon (Fig. 10). Since the valley marks the meeting place of tectonic plates and preserved remnants of the rifting and birth of the Tethyan Ocean within an extant Pangaeanaged setting, the petrologic diversity in so small an area as this is perhaps among the greatest on earth: in addition to ophiolitic lithologies of all parts of the lithospheric section and "Pangaean" rocks, the metamorphic meeting zone includes its own stratotectonic mélange, and "new" intrusions into the deforming zone. Even statistical sedimentary "cobble counts" within the valley gave rise to new problems that couldn't be addressed in the short scale of the program (Fig 11: we have yet to locate the immediate provenance of the unaltered ophiolitic gabbroic rocks that are well-preserved within the river cobbles).

Were there significant changes made in the interpretation of this paradigm locality of plate tectonic theory? A comparison (Rassios et al., 2016, p. 262) of a short description of the Aliakmon Section predating the project can be compared to the current model, synthesized from the work of the Aliakmon Legacy research group:

The Pre-Legacy Project Model (Rassios, 2004): “The Vourinos Ophiolite is emplaced over the Pelagonian Massif with "bulldozed' foreland basin deposits entrapped in the collision zone and imprinted by metamorphism of the hot sole." 

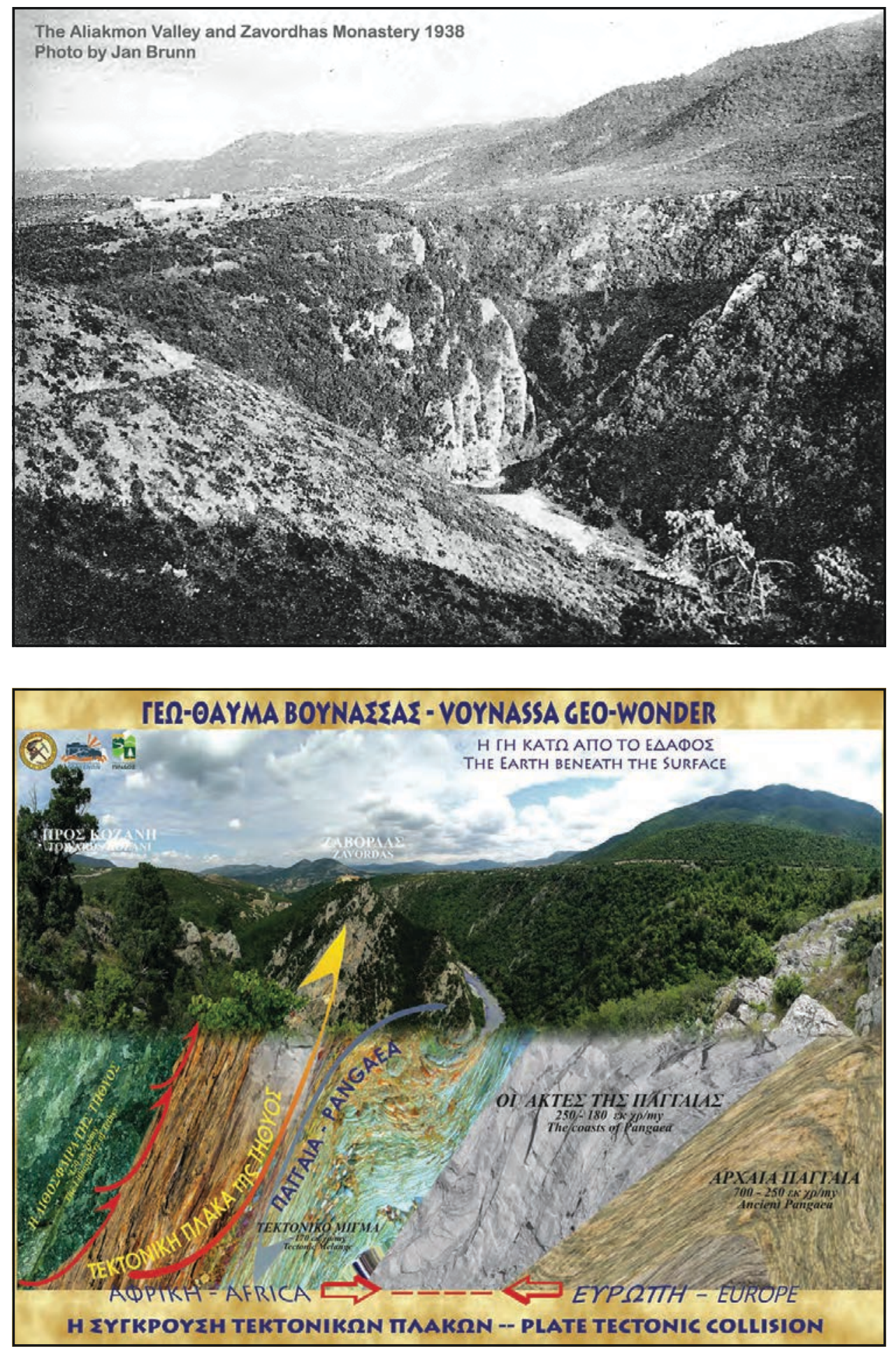

Figure 8. Geoheritage within the Aliakmon River Valley of Vourinos. (A) The earliest known photograph of the Aliakmon River Valley ophiolitic sole by Jan Brunn, taken in 1938 using a glass-plate photographic technology. As Jan explained, he could not depend on finding film for sale in this out-ofthe-way region of Greece. The photo includes the view of what is possibly the earliest photograph of the Zavordas Monastery, founded in 1534 AD, at a geomorphologically controlled site. The photograph is also useful for comparison of the environmental and vegetation conditions present in 1938 with those of today. This photo was one of Jan's that inspired John Maxwell of Princeton in the 1960s to find funding for the research of Eldridge Moores and Jay Zimmerman for their critical studies and hence, a major understanding of ophiolites, oceanic lithosphere and plate tectonic theory. This photo can be considered one of the archetypical points of geoheritage history. (Photo courtesy of Jann Brunn.) (B) The collision zone of Vourinos (Jurassic Tethyan Lithosphere) with the Pangaean (Pelagonian) continental margin as reconstructed by the Aliakmon Legacy Project. This poster is a popular geotouristic display in the region. (Photo by A.E. Rassios.)
The Current Model: "The Vourinos Ophiolite is bounded along its north and south margins by transcurrent faults (Rassios and Moores, 2006; Rassios and Dilek, 2009) that accommodated complex compressional and strike-slip deformation as they displaced the ophiolite to the northeast (Ghikas, 2007). In the southeastern extreme of the ophiolite, the fault is a wide zone, approaching a $\mathrm{km}$ in width, wherein the ophiolite-river section is overprinted by tectonic motions that record a thrust environment of NE-movement with a 'splay' to the SE as the thrust complex rotated its own margins/footwall as it moved forward. Garnets and amphiboles within the sole contact indicate formation at temperatures of $\sim 770{ }^{\circ} \mathrm{C} \pm 100{ }^{\circ} \mathrm{C}$ and pressures of $4 \pm 1 \mathrm{kbar}$; 

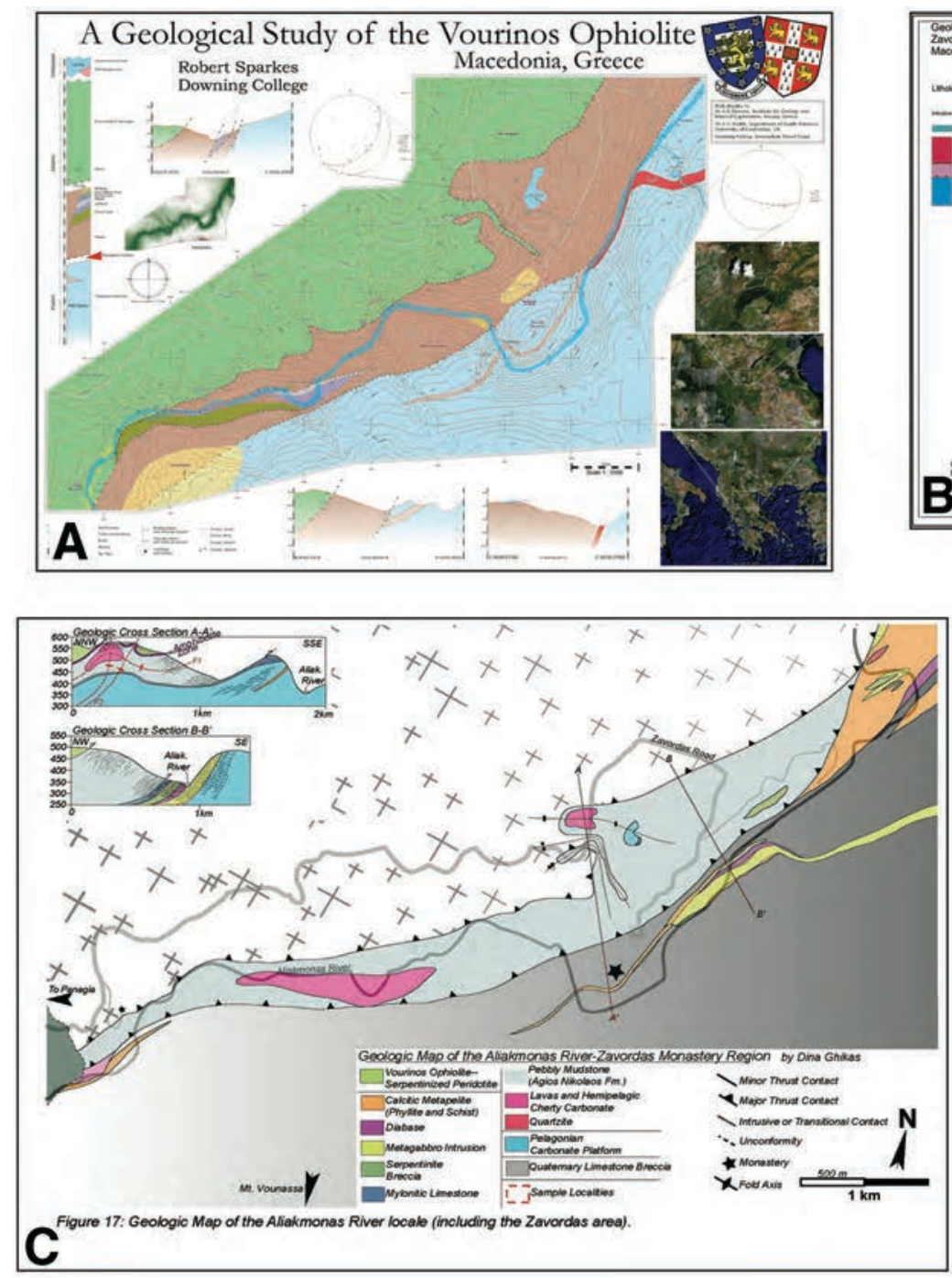
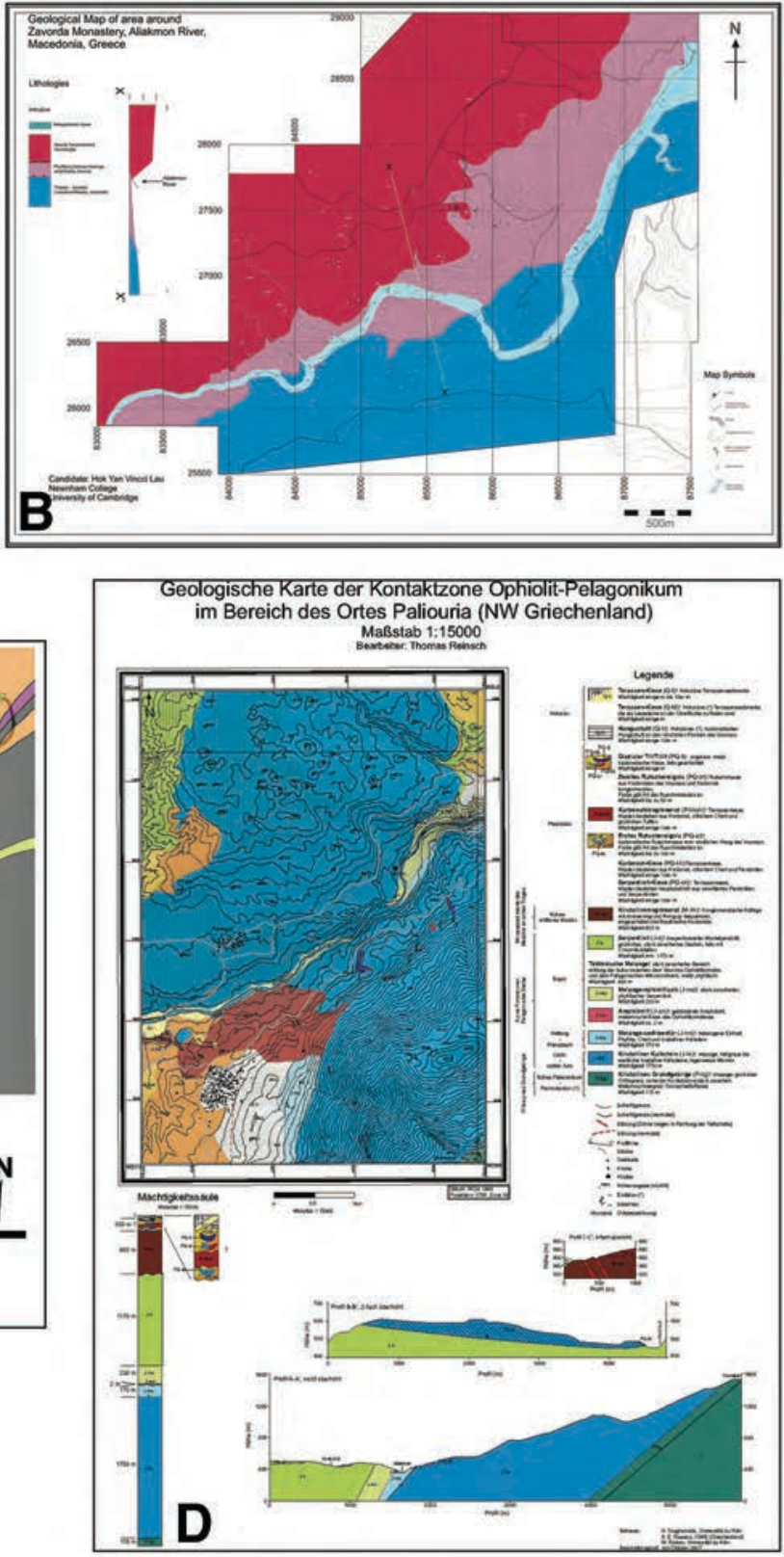

Figure 9. Representative student maps of the geoheritage area; the introduction of GIS-based technology to the geoheritage sites first studied in the 1960s. (A) R. Sparkes; (B) V. Lau; (C) C. Ghikas; (D) T. Reinsch. We present these very much reduced images to show that the maps produced in this study (40 in total) exemplify differing mapping styles and allow for interpretation to differ between the students.

that is, the sole provenance would have been very close to the spreading system that created the ophiolite (Myhill, 2008, 2011). Within the Aliakmon River valley, kinematic motions are depicted ranging from ductile to brittle conditions. Along the Aliakmon River section, these movements merge the original ophiolitic emplacement over mélange sediments with the transcurrent deformation environment: the fault-emplacement zone along the river section includes plastic deformation of host Pelagonian carbonates, intercalation of highly deformed and altered ophiolitic material, and remnants of the garnet amphibolite/ amphibolite ophiolitic sole, and preserves older (Triassic) rifting lavas and sedimentation dating from the break-up of Pelagonia. The river section is intruded by 'leaks' of younger basalt and gabbro within the internal zone of the transcurrent fault, some extending into older Pelagonian country rock. The southernmost contact of the transcurrent fault formation parallels the extension of the Servian Fault along Mount Vounassa, implying that this massive variation in rock competency accounted for the fault's location. Thus, the transcurrent fault (dating to the Mesozoic) once exposed along the Aliakmon River section is demonstrated 


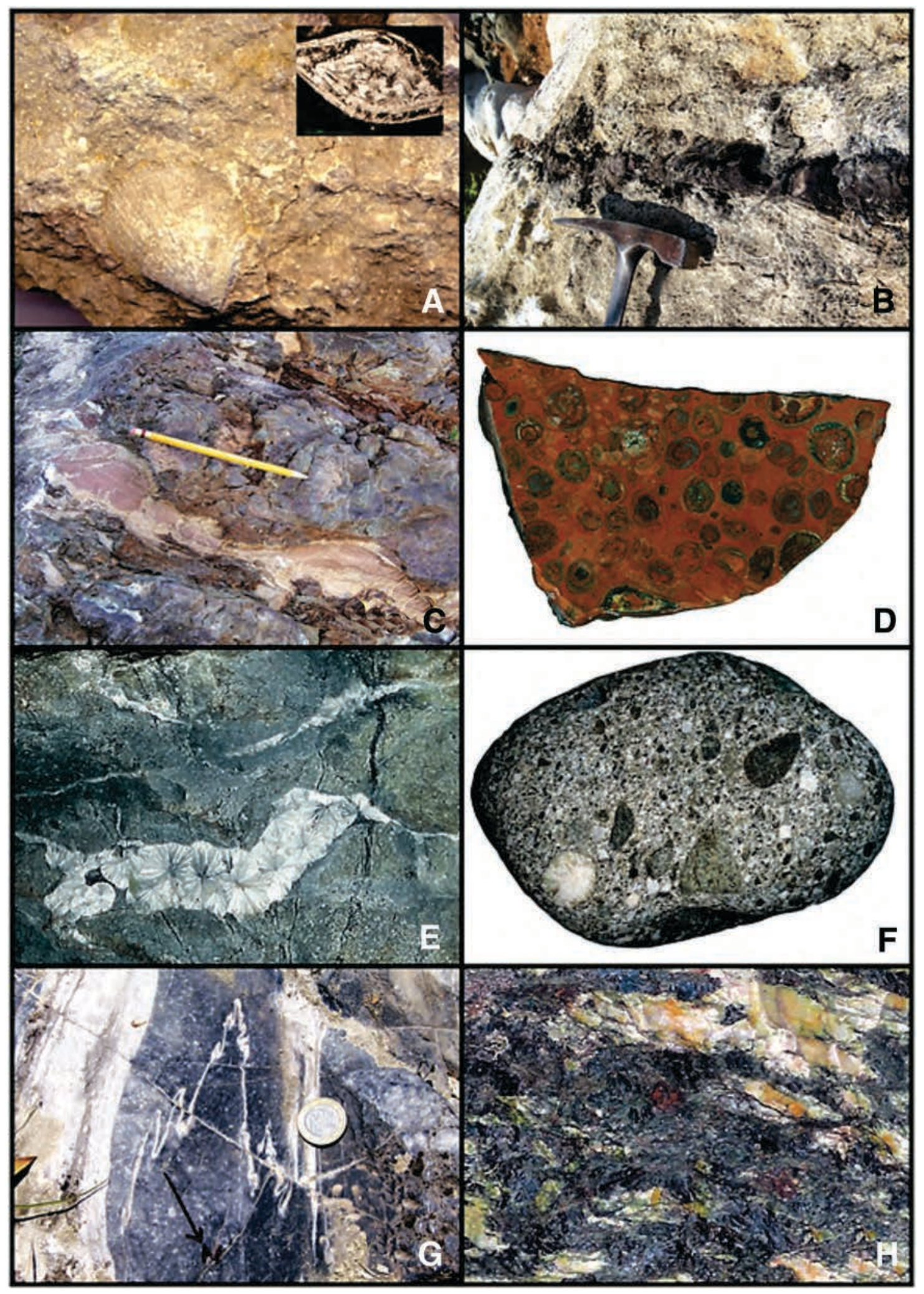

Figure 10. Representative GPS photos and samples that document the geoheritage of the now-flooded Aliakmon geoheritage sites. (A) Cretaceous ocean fossils in limestone deposited onto the newly emplaced ophiolite. (B) An undeformed "relatively young" dike crossing the deformed interior of the Aliakmon Valley. (C) Deformed Jurassic pillow lavas and sediments. (D) Oolitic Jurassic radiolarian chert. (E) Zeolite mineralization within basalt. (F) Cobble of greywacke material found within riverbed. (G) Deformed Mesozoic carbonates, footwall to ophiolitic emplacement (H) Garnet amphibolite sole from the obduction zone. 


\begin{tabular}{|l|}
\hline$\square$ Chert \\
$\square$ Calcite (veins) \\
$\square$ Conglomerate \\
Basait(Diabase) \\
$\square$ Gabbro \\
$\square$ Gneiss/Mica Garnet Schist \\
$\square$ Greenschist/Amphibolite/Green \\
rock(?) \\
Harzburgite. Serpentinised \\
Limestone \\
$\square$ Marble \\
$\square$ Mart \\
$\square$ Peridotite \\
Quartzite \\
$\square$ Phyllite \\
$\square$ Sandstone/Siltstone \\
$\square$ Spillite \\
$\square$ Serpentinite \\
$\square$ Troctolite \\
\hline
\end{tabular}

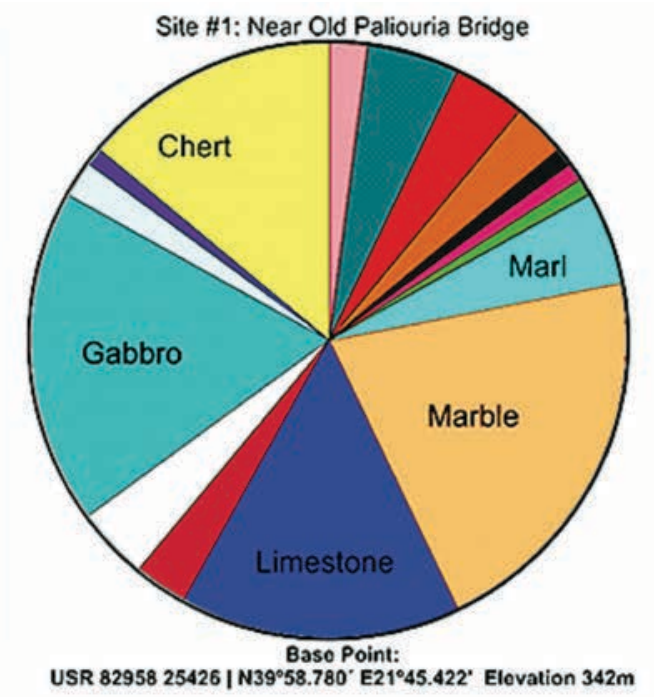

Site \#2: South Side of River from Panayia Monastery

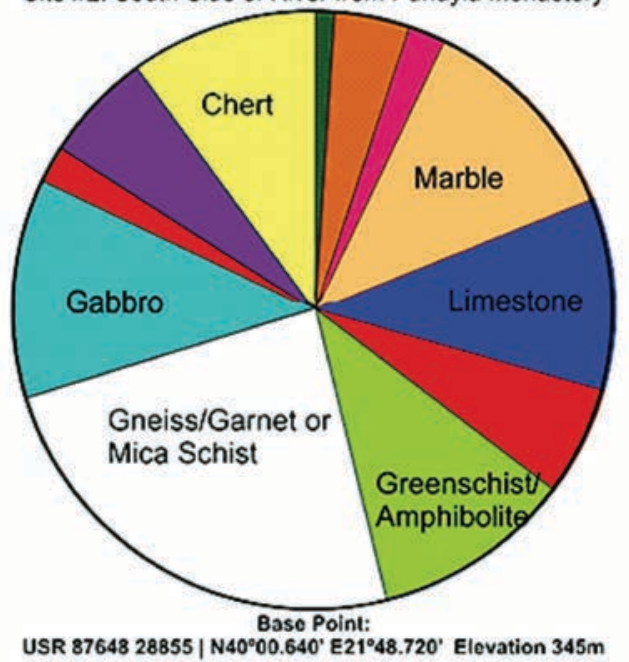

Figure 11. Representative "cobble counts" of deposits within the now-flooded Aliakmon Valley. The "counts" located a high proportion of unaltered gabbro of unknown provenance.

to comprise a major tectonic feature parasitically facilitating and recording over 200 million years of tectonic history of the Pelagonian-Tethyan margin."

The critical Aliakmon River section, one of the birthplaces of plate tectonic theory, is now flooded. With our maps and studies, and with the rock and photographic collections, some parts of its geoheritage are preserved; however, the real value of this project lies in the preservation of a knowledge base by those students who participated and who, in the future, will use what they learned in the study to pass this significant geoheritage to their students and colleagues. The key geoheritage sites of plate tectonic theory were visited in the final international field trip to the river in 2008 (Rassios et al., 2008).

\section{A "CUTTING-EDGE" PROPOSAL FOR THE METEORA WORLD HERITAGE SITE}

The preceding section demonstrated the capability of an integrated geoscientific approach to updating the understanding of a classic geoheritage site: cultural ramifications of site location and post-Byzantine society were not addressed. We encourage the study of culturally more significant sites to expand the framework integration of geoheritage with cultural heritage. Among sites that would benefit from such studies and provide important cultural and historic cutting-edge knowledge, would be the application of geoheritage studies to UNESCO World Heritage sites. As an example of the potential of such a study, we include a proposal for study of the Meteora World Heritage Site (Thessaly, Greece).

The raison d'être of the Byzantine monastic community of Meteora is its spectacular geologic landforms (Fig. 12A and 12B; location included on Fig. 1B). These rock spires draw an estimated million tourists annually to the area. Surprisingly, the comprehensive geology of these landforms has never been studied in detail. In comparison to the level of research and geologic interpretation provided to the general public within the national parks of Great Britain or the United States, the visitor to Meteora is left with no reliable information on the processes, nature, age, or uniqueness of the geologic environment he/she has visited. There are few academic studies of the Meteora region: those that exist represent specialist disciplines (for example, Gilbert deltas by Ori and Roveri, 1987; basin formation by Zelilidis, 2003; regional tectonics by Vamvaka et al., 2006). In-depth transdisciplinary scientific investigations of the geological evolution of the special rock formation that makes up the pinnacles and the processes of pinnacle formation are lacking (Rassios et al., 2020). It is obvious that without these unique geological structures, the cultural history of Meteora would be distinctly different than it is today.

\section{Sketch of Background Geology/Geography}

Following decades of touristic visits to the Heritage Site, Rassios et al. (2013a, 2013b, 2020) documented a framework model that essentially formulates the questions that need to be addressed in an advanced study, as follows.

The immediate area (Fig. 12A) including the landforms of Meteora is only $\sim 6 \mathrm{~km}^{2}$, though outcrops of Meteora Conglomerate extend several additional kilometers to the south and north. The area has not been mapped except on 1:50,000 scale as part of the Kalambaka sheet of the Geologic Map of Greece (Savoyet et al., 1972). The mapping and data of this sheet date from the work of Jan Brunn, who conducted his research from 1938 to 1940, and published his dissertation in 1956. The only significant study of the area since then is a short paper (Ori and Roveri, 1987) describing the conglomerates as Gilbert-style deltas (a river delta 

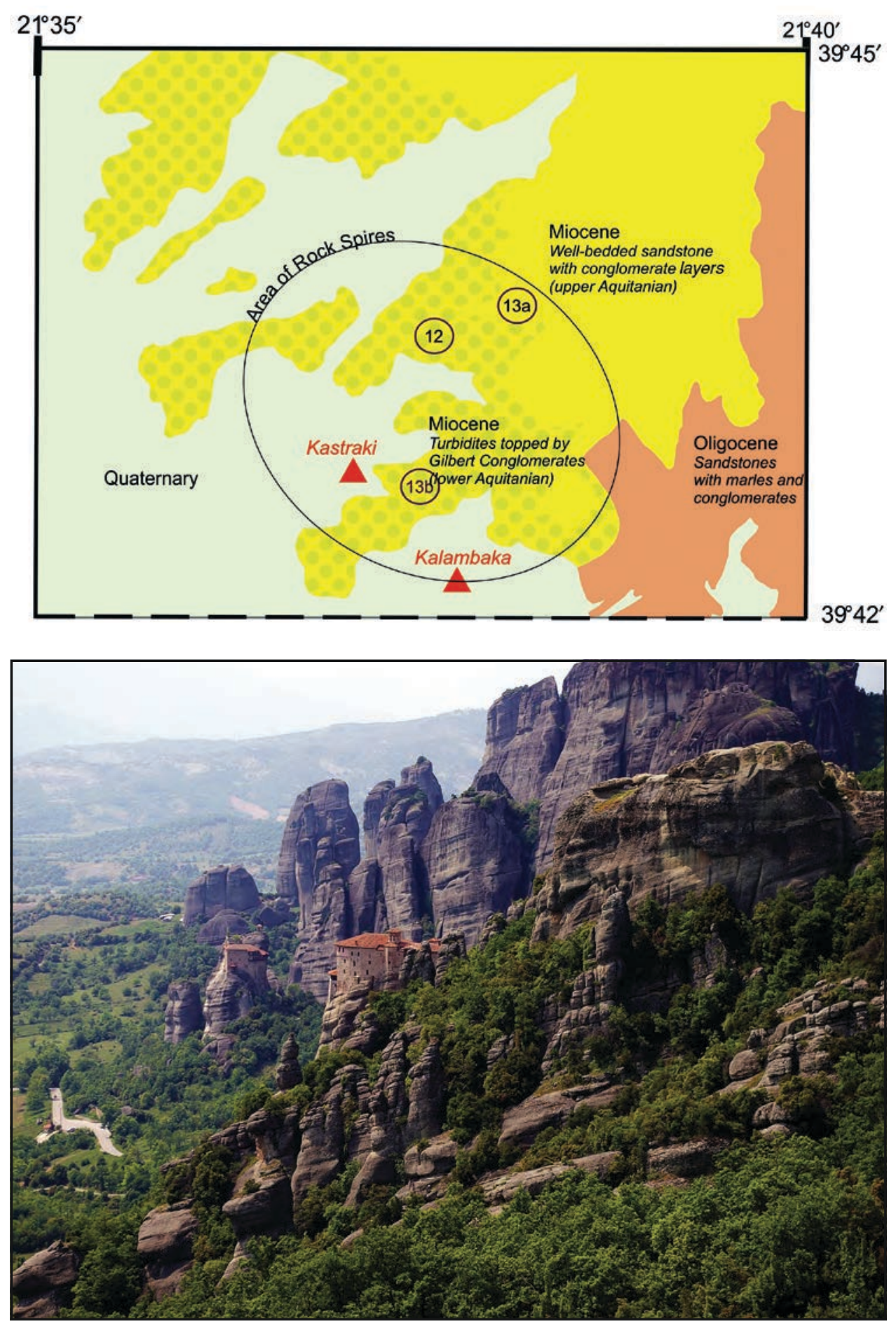

Figure 12. (A) General geology of the area of the Meteora Rock Spires: Map after Brunn (1956) and Savoyet et al. (1972). Small, circled numbers refer to position of Meteora photos within this study. (B) Panoramic view of the Meteora World Heritage Site. (Photo by A. Rassios). Turbiditic layered sandstones with "Gilbert" conglomerate deltas in upper part of photo. composed of coarse sediments of high energy deposition). Studies of provenance, ages, material competence, and erosional processes - the very features that are crucial in the development of the Meteora landforms - have never been conducted.

The Meteora conglomerates, dated as Aquitanian by Brunn (1956), are deposited on fossil-dated Oligocene sandstones and marls of the Eptahori group of Mesohellenic sediments. Initial observations of this contact suggest that the hiatus between these formations corresponds with a major change in depositional source area, and indeed, the Meteora conglomerates might have been deposited by scouring and filling-in of near shore submarine canyons within the Oligocene (a process of similar scale is on-going today off the California coast, for example, at Malibu). If so, then the elongated morphology of the landforms of 
Meteora could partly be due to the topography of these initial submarine canyons.

The provenance area (Fig. 1A) of the region that contains rock types similar to those found as cobbles within the Meteora conglomerates is over $3000 \mathrm{~km}^{2}$, extending NE to Mount Olympos (crossing the Pelagonian metamorphic complex, an exhumed Pangaean subcontinental terrane), north toward the Vourinos Ophiolite (a mid-Jurassic section of oceanic lithosphere) and ESE to Larissa. It is within this region that the cobbles of Meteora originate, as well as the tectonic processes that created the rare erosional "trigger" instigating deposition of the high-energy cob- ble deposits. Of note, the presence of blueschist cobbles requires the conglomerates a provenance including the Mount Olympos exhumation zone. The provenance area must have provided a rapid, elevated tectonic "high" in order to produce the rock slurry (turbidite) deposits of Meteora (Figs. 13A and 13B).

The deposition of the Meteora conglomerates, the processes resulting in their lithification into a "natural concrete," and the formation via erosion of the rock spire landforms of today are among the geo-events that have not yet been incorporated into a modern tectonic model of Greece. The documentation and dating of multiple uplifts, multiple erosional periods and peneplain
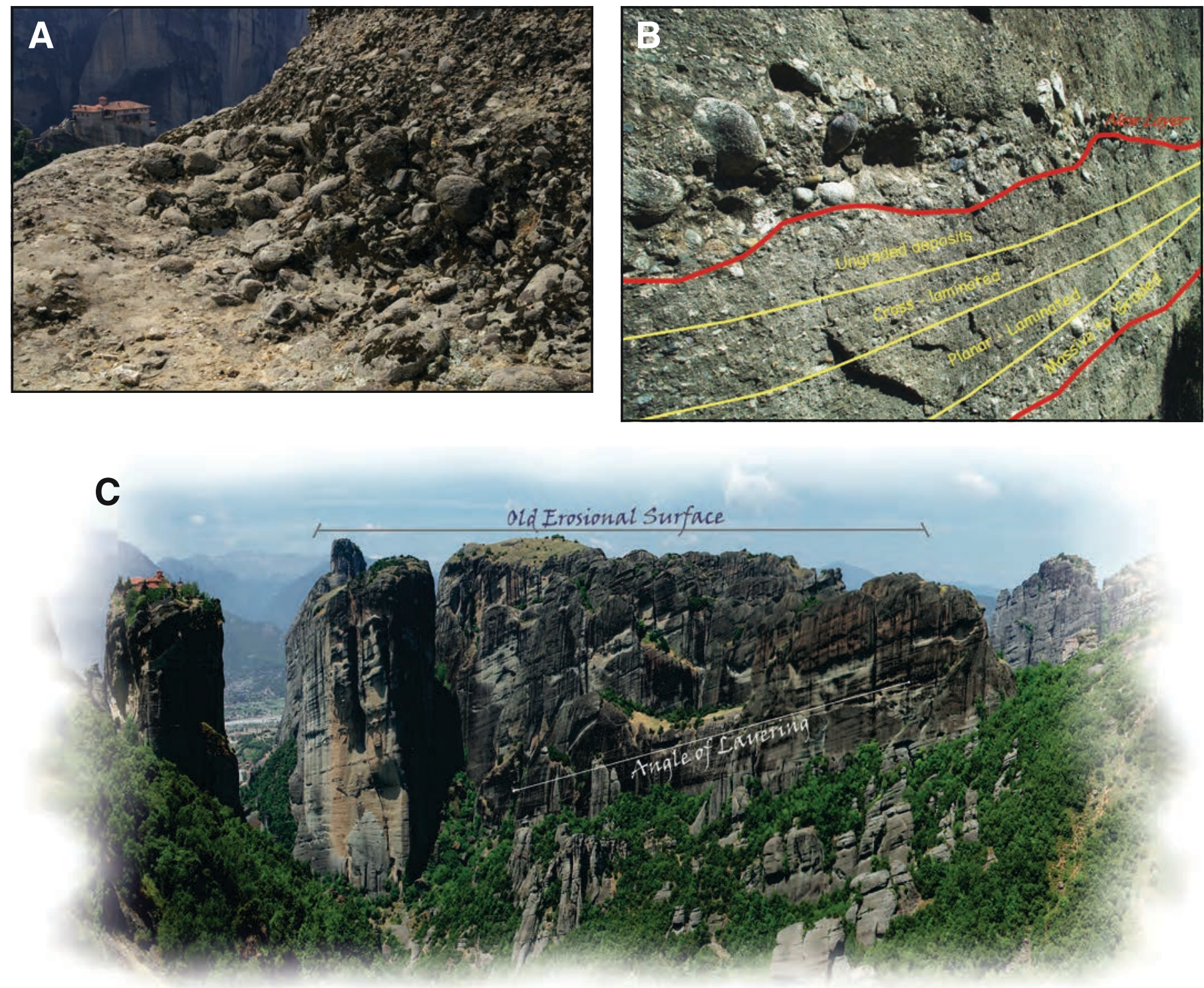

Figure 13. Conglomerates (A) deposited onto turbiditic layered sediments (B) of the Meteora World Heritage Site. The association of these members, as well as inferences from syn-depositional geomorphology, suggests a geo-environment similar to that along the coast of Southern California today. Such an analogy requires serious renewal of the consensus interpretation of Greek geology. (C) This photo demonstrates the erosional peneplain surface that preceded formation of the rock spires. 
formation at Meteora will provide accurate data toward reconstructing the latest 40 million years of regional history. Establishing this link between the origin of the erosional epoch creating the rock slurries of the conglomerates and their deposition is essential to understanding the exhumation of the Pelagonian (Pangaean-aged) core complex and of Mount Olympos with shoreline conditions of the Tertiary.

There is no agreement on the age of the rock spires themselves. Some sources contend that they are less than 2000 years old since they are not mentioned in classical Greek texts or mythology. Some current tourist brochures place them as contemporaneous with dinosaurs for no stated reason. The level of scientific knowledge of this world heritage site is an embarrassment to the geologic community and a severe shortcoming to touristic appreciation.

The Meteora Peneplain (Fig. 13C) is visible as a surface common to the upper exposures of the rock spires that preceded their erosion to geomorphologic "hoo-doos," and has been roughly dated to $\sim 700,000$ years via regional archaeological studies (N. Wilke, 2003, personal commun.). Climactic conditions of the Plio-Pleistocene promoted preferential erosion of the rock spires including drainage and/or flooding, ice fracturing, and vegetation. Anthropological history dates well into the Neanderthal/Paleolithic era as early humans settled the microclimate areas of the heritage site and, perhaps, played a further role in the ecologic and geologic evolution of Meteora.

What is the geologic future of these fragile formations? How will climate change affect ongoing erosional processes? Can we estimate their "strength" in the locally active seismic environment? Does human access, even with such subtle actions as the use of pitons during rock climbing, threaten the integrity of the landforms?

The study of such a geoheritage-World Heritage Site, and a similar philosophy of study at other World Heritage Sites, would benefit an integrated geologic and cultural knowledge base. Young scientists must become involved in studies of this nature as they assume the role of the custodians of our changing physical world.

\section{IMPLICATIONS AND CONCLUSIONS FOR INTEGRATED GEOHERITAGE AND CULTURAL HERITAGE}

From the Aliakmon heritage study and Meteora proposal described, it becomes obvious that new discoveries (below) of a single "subtle" stray dike or of a cobble of blueschist can totally rewrite what is understood of the origin of a geoheritage site, and cause us to consider how sensitive geologic evolution is as a process affecting scientific models and cultural development:

- The discovery of undeformed basalt/gabbro dikes in the Aliakmon Valley demonstrates a new, different tectonic role of the valley, one that dates from the original rifting of Pangaea to transform movement during ophiolite emplacement. If the Aliakmon Valley somehow was not exposed for study, if the dam that obliterated its critical section been built before the 1960s, how would the initial documentation of plate tectonic history have changed?

- At Meteora, the discovery of sparse fragments of blueschist within the conglomerate formation ties the history of the heritage site to that of the exhumation of Mount Olympus: were there no Mount Olympus, there would be no Meteora, no rock spires, and no Byzantine monastic community.

The meaning of such "simple" geologic features would have been incomprehensible in the geologic knowledge base of the late 1960s; the role of an intrusion into a ductile fault zone or of the significance of blueschist in exhumation theory were totally unknown. In today's geological knowledge base, these features become critical in understanding key turning points within geological history that, if different in nature, could have taken geologic and human history in very different directions. We presume that the presence of these subtle but critical keys to the development of our modern world are present in other exemplary geoheritage and World Heritage Sites. To quote Neil deGrasse Tyson, "Nature can be subtle."

It is naturally occurring subtleties that lead to advancements in the study of the universe at large. As geoscientists, perhaps we could emulate the quest for a coherent understanding of the universe when we apply ourselves to formulate a complete geologic understanding of a site as important to human civilization as is a World Heritage Site.

- World Heritage and internationally recognized Geoheritage Sites as present in geoparks are not geologic "type" specimens gathering dust within a museum; they are the sites that formed and defined humanity, science, and civilization itself.

- The "geologic consent" that created a heritage area such as Meteora or a civilization icon such as the Acropolis is not a single event, but a near billion-year history that needs articulation beyond specialized geological interests.

- The overlap between geological phenomena with archaeological or social development leads to innovative interpretations of the importance of geology to humanity and critical historic events.

- It is our opinion that geoheritage is perhaps one of the most important but overlooked scientific specialty fields. The recognition of this field requires the kinds of studies that attain its cutting-edge potential; that is, studies that require the formulation of a completely new branch of geological specialization to explain the importance of geology to civilization.

Following the philosophic lead of Will Durant as encouraged by Eldridge Moores, we invite speculation as to whether such thoughts are the initiation a new "paradigm" of research. To reiterate: Geoheritage is the union of the study of geology as a science with the recognition and importance of geology to human society. The study of geoheritage needs to live up to this definition. 


\section{ACKNOWLEDGMENTS}

Considering geoheritage within an extended research paradigm came about during the instruction of a short course by Rassios at the University of Milan in 2016 with Giovanni Grieco. We thank the students who participated in this course and in the Aliakmon Legacy Project, and particularly we appreciate the late Eldridge Moores for inspiring these thoughts over the past 40 years.

The Aliakmon Legacy Project was encouraged by the International Union of Geological Sciences. The Public Power Corporation of Greece is especially thanked for its funding of the Aliakmon Legacy Project; the program was carried out by the Institute of Geology and Mineral Exploration of Greece.

We thank Judy Moores for searching down the original publication of the famous quote by Will Durant. We thank our reviewers and the GSA editor for excellent suggestions that improved this paper. Our original draft was reviewed by Eldridge Moores; he suggested its inclusion in this volume. This is indeed an "Eldridge Moores" paper in spirit.

\section{REFERENCES CITED}

Aksu, A.E., Hiscott, R.N., Mudie, P.J., Rochon, A., Kaminski, M.A., Abrajano, T., and Yaar, D., 2002, Persistent Holocene outflow from the Black Sea to the Eastern Mediterranean contradicts Noah's Flood hypothesis: GSA Today, v. 12, no. 5, p. 4-10, https://doi.org/10.1130/1052-5173 (2002)012<0004:PHOFTB >2.0.CO;2.

Alvarez, L., Alvarez, W., Asaro, F., and Michel, H., 1980, Extraterrestrial cause for the Cretaceous-Tertiary extinction: Science, v. 208, no. 4448, p. 1095 1108, https://doi.org/10.1126/science.208.4448.1095.

Barker, J.P., and Barker, J.M., 1988, Geoanthropology, in Encyclopedia of Earth Sciences: Springer U.S., p. 218-223.

Brocx, M., and Semeniuk, V., 2007, Geoheritage and geoconservation-history, definition, scope and scale: Journal of the Royal Society of Western Australia, v. 90, p. 53-87.

Brunn, J., 1956, Contribution a L'Étude Géologique du Pinde Septentrional et D’une Partie de la Macédoine occidentale: Annales Géologiques des Pays Helléniques, v. 7, p. 1-358.

Dimitrov, P., and Dimitrov, D., 2004, The Black Sea, the flood, and the ancient myths: Varna, Bulgaria, Slavena, $91 \mathrm{p}$.

Durant, W., 1946, "What is Civilization?”: Ladies Home Journal, January issue.

Fassoulas, C., Mouriki, D., Dimitriou-Nikolakis, P., and Iliopoulos, G., 2012, Quantitative assessment of geotopes as an effective tool for geoheritage management: Geoheritage, v. 4, no. 3, p. 177-193, https://doi.org/ 10.1007/s12371-011-0046-9.

Ghikas, C., 2007, Structure and Tectonics of a Subophiolitic Mélange (Zavordas Mélange) of the Vourinos Ophiolite (Greece) and Kinematics of Ophiolite Emplacement [MSc thesis]: Ohio, USA, Miami University, 121 p.

Ghikas, C., Dilek, Y., and Rassios, A., 2010, Structure and tectonics of subophiolitic mélanges in the western Hellenides (Greece): implications for ophiolite emplacement tectonics: International Geology Review, v. 52, no. 4-6, p. 423-453, https://doi.org/10.1080/ 00206810902951106 .

Heiken, G., Funiceillo, R., and De Rita, D., 2007, The Seven Hills of Rome: A Geological Tour of the Eternal City: Princeton University Press, 264 p.

Kuhn, T., 1962, The Structure of Scientific Revolutions: University of Chicago Press, $172 \mathrm{p}$.

Leleniczi, M., 2009, Geotope, geosite, geomorphosite: Annals of Valahia University of Târgovişte, Geographical Series, v. 9, p. 9-22.

Mariolakos, I., 1998, The geomythological geotope of Lerni Springs (Argolis, Greece): Geologica Balcanica, v. 28, no. 3-4, p. 101-108.

McKeever, P., Zouros, N., 2005, Geoparks: Celebrating Earth heritage, sustaining local communities, Episodes, v. 28, p. 274-278.
Moores, E.M., 1969, Petrology and structure of the Vourinos ophiolitic complex of northern Greece: Geological Society of America Special Paper 118, 74 p, https://doi.org/10.1130/SPE118-p3.

Moores, E.M., 2003, A personal history of the ophiolite concept, in Dilek, Y., and Newcomb, S., eds., Ophiolite Concept and the Evolution of Geological Thought: Geological Society of America Special Paper, v. 373, p. 17-29, https://doi.org/10.1130/0-8137-2373-6.17.

Moores, E.M., 2018, Video recording describing the inception of the Geopark concept by the IUGS and applicability to the Vourinos area: Personal recording by Judy Moores, available at https://1drv.ms/v/ s!AoNXiIoq6WZklHfvKiCyYpp4hEJp or https://drive.google.com/ file/d/1D0QXQNKP3Q-KJeoM-CoICPVj3hMiYdFD/view (accessed May 2021).

Myhill, R., 2008, Metamorphic Development beneath the Pindos-VourinosOphiolite Slab [MSc thesis]: Cambridge University, $125 \mathrm{p}$.

Myhill, R., 2011, Constraints on the evolution of the Mesohellenic ophiolite from subophiolitic metamorphic rocks, in Wakabayashi, J., and Dilek, Y., eds., Mélanges: Processes of Formation and Societal Significance: Geological Society of America Special Paper 480, p. 75-94, https://doi .org/10.1130/2011.2480(03).

Ori, G.G., and Roveri, M., 1987, Geometries of Gilbert-type deltas and large channels in the Meteora conglomerate, Meso-Hellenic basin (OligoMiocene), central Greece: Sedimentology, v. 34, no. 5, p. 845-859, https://doi.org/10.1111/j.1365-3091.1987.tb00808.x.

Rassios, A., 2004, A Geologist's Guide to West Macedonia, Greece: AnGre, Grevena, Greece, 120 p.

Rassios, A.E., and Dilek, Y., 2009, Rotational deformation in the Jurassic Mesohellenic ophiolites, Greece, and its tectonic significance: Lithos, v. 108, p. 207-223, https://doi.org/10.1016/j.lithos.2008.09.005.

Rassios, A.E., and Moores, E.M., 2006, Heterogeneous mantle complex, crustal processes, and obduction kinematics in a unified Pindos-Vourinos ophiolitic slab (northern Greece): Geological Society, London, Special Publication 260, p. 237-266, https://doi.org/10.1144/GSL.SP.2006.260.01.11.

Rassios, A., Smith, A., and Kostopoulos, D., 2008, Guidebook Ophiolites 2008: Link between the Mesohellenic Ophiolites and Pelagonian Margin, West Thessaly and West Macedonia, Greece: Institute of Geology and Mineral Research (Athens, Greece), 88 p., reprinted in Virtual Explorer, 2009: http://www.virtualexplorer.com.au/journal/2009/34/.

Rassios, A., Ghikas, C., and Batsi, A., 2013a, The Birth of Meteora, Geowonders of the Pindos: Grevena, Greece, $48 \mathrm{p}$.

Rassios, A., Vamvaka, A., Batsi, A., and Ghikas, C., 2013b, Meteora: the stories behind the geology of the international heritage site: Deposits, v. 30 .

Rassios, A., Grieco, G., Batsi, A., Myhill, R., Ghikas, D., 2016, Preserving the non-preservable geoheritage of the Aliakmon River: a case study in geoeducation leading to cutting-edge science: Bulletin of the Geological Society of Greece, v. 50, p. 255-264.

Rassios, A., Ghikas, D., Dilek, Y., Vamvaka, A., Batsi, A., and Koutsovitis, P., 2020, Meteora: A billion years of geological history in Greece to create a World Heritage Site: Geoheritage: v. 12, article no. 83, 16 p., https://doi .org/10.1007/s12371-020-00509-9.

Raynaud, S., de la Boisse, H., Mahmoud Makroum, F., and Bertho, J., 2008, Geological and geomorphological study of the original hill at the base of Fourth Dynasty Egyptian monuments: HAL open archive, 22 p., https:// hal.archives-ouvertes.fr/hal-00319586 (accessed April 2021).

Ryan, W., 2007, Status of the Black Sea flood hypothesis, in Yanko-Hombach, V., Gilbert, A., Panin, N., and Lolukahnov, P., eds., The Black Sea Flood Question: Changes in Coastline, Climate, and Human Settlement: Springer, p. 63-88, https://doi.org/10.1007/978-1-4020-5302-3_4.

Ryan, W.B.F., Major, C.O., Lericolais, G., and Goldstein, S.L., 2003, Catastrophic flooding of the Black Sea: Annual Review of Earth and Planetary Sciences, v. 31, p. 525-554, https://doi.org/10.1146/annurev.earth 31.100901.141249.

Savoyet, E., Lolehou, N., and Bizon, G., 1972, Geologic Map of Greece, KALAMBAKA Sheet: Athens, Greece, Institute of Geology and Mineral Exploration, 1:50,000 scale.

Schama, S., 1995, Landscape and Memory: Alfred A. Knopf, New York, p. 652. Schulte, P., Alegret, L., Arenillas, I., Arz, J., Barton, P., Bown, P., Bralower, T., Christeson, G., Claeys, P., Cockell, C., Collins, G., Deutsch, A., Goldin, T., Goto, K., Grajales-Nishimura, J., Grieve, R., Gulick, S., Johnson, K., Kiessling, W., Koeberl, C., Kring, D., MacLeod, K., Matsui, T., Melons, J., Montanari, A., Morgan, J., Neal, C., Nichols, D., Norris, R., Pierazzo, E., Ravizza, G., Rebolledo-Vieyra, M., Reimold, W., Robin, E., Salge, T., 
Speijer, R., Sweet, A., Urrutia-Gucugauchi, J., Vajda, V., Whalen, M., and Willumsen, P., 2010, The Chicxulub asteroid impact and mass extinction at the Cretaceous-Paleogene boundary: Science, v. 327, p. 1214-1218, https://doi.org/10.1126/science.1177265.

Semeniuk, V., 1997, The linkage between biodiversity and geodiversity, in Eberhard, R., ed., Pattern \& Processes: Towards a Regional Approach to National Estate assessment of geodiversity: Australian Heritage Commission \& Environment Forest Taskforce, Environment Australia, Canberra, Technical Series No. 2, p. 51-58.

Vamvaka, A., Kilias, A., Mountrakis, D., and Papaoikonomou, J., 2006, Geometry and structural evolution of the Mesohellenic Trough (Greece): a new approach, in Robertson, A.H.F., and Mountrakis, D., eds., Tectonic Development of the Eastern Mediterranean Region: Geological Society of London Special Publication 260, p. 521-538, https://doi.org/10.1144/ GSL.SP.2006.260.01.22.

Zelilidis, A., 2003, The geometry of fan-deltas and related turbidites in narrow linear basins: Geological Journal, v. 38, p. 31-46, https://doi.org/10.1002/ gj. 925 .
Zimmerman, J., 1968, Structure and Petrology of Rocks Underlying the Vourinos Ophiolitic Complex [PhD thesis] Princeton University, 98 p.

Zimmerman, J., 1969, The Vourinos Complex-An allochthonous alpine ophiolite in Northern Greece: Geological Society of America Abstracts with Programs, v. 1, no. 7, p. 245.

Zimmerman, J., 1972, Emplacement of the Vourinos ophiolitic complex, northern Greece, in Shagam, R., et al., eds., Studies in Earth and Space Sciences: Geological Society of America Memoir 132, p. 225-239, https:// doi.org/10.1130/MEM132-p225.

Zouros, N., 2004, The European Geoparks Network: Geological heritage protection and local development: Episodes, v. 27, no. 3, p. 165-171, https:// doi.org/10.18814/epiiugs/2004/v27i3/002.

Manuscript ACCePted by the Society 2 April 2021

Manuscript Published Online 20 August 2021 
